\title{
Explicit and Implicit Social Studies: \\ Exploring the Integration of Social Studies Experiences in Two Elementary Classrooms
}

\author{
Kristy A. Brugar \\ Associate Professor, Social Studies Education \\ University of Oklahoma \\ kristy.a.brugar@ou.edu \\ Annie McMahon Whitlock \\ Associate Professor of Elementary Education \\ University of Michigan-Flint \\ annie.whitlock@gmail.com
}

\begin{abstract}
This study explores how two elementary teachers (first and fifth grades) integrated social studies content and skills throughout their school day. More specifically, we describe and explain their social studies instruction in terms of integration as it reflects fractured, healthy, and stealthy integration (Hinde, 2015). As researchers, we spent time in two classrooms documenting the explicit and implicit social studies instruction and the interactions of teachers and students. We found examples of fractured, healthy, and stealthy integration with most instances occurring throughout the school day but with varying degrees of transparency. This study provides insight to what is taught as elementary social studies and the study contributes to our understanding of how social studies is taught in elementary classrooms with implications for future research and teacher practice.
\end{abstract}

In her first-grade classroom, Jules ${ }^{1}$ put on a song to transition her students from their morning work to the carpet to begin their day. The students know that when the song ends, they must be sitting on the carpet. The familiar tune of "The Hello Song" (by a folk duo named Gemini) begins:

"Hello, hello, hello

Hi, hi, hi

Hello, hello, hello, hi!

In France, they say bonjour

In China, they say ni hao

In Japan, they say kon'nichiwa

And in India, they say namaste...namaste!"

\footnotetext{
${ }^{1}$ All names are pseudonyms
} 
Jules and the first graders sing along with the next verse of the song, excitedly singing "hello" in different languages. The song ends and Jules begins her calendar time on the whiteboard. At one point, Jules asks the students to count to ten all together. After they count to ten in English, Jules asks, "Should we count to ten in Japanese next? Haruka, can you lead us?" Haruka, a Japanese English Language Learner (ELL) student, leads the class in counting to ten in her first language, and the class joins in, as this is a regular routine in their classroom.

Transitioning students to the carpet for whole group instruction on the daily calendar is a common occurrence in early elementary classrooms. In Jules' classroom, this was also an opportunity for her to integrate social studies concepts related to cultural geography and diversity (e.g., languages, regions). She did this by highlighting the variety of languages spoken by students in her classroom from Japanese to Spanish. This recognition of multilingualism was done not overtly with an announcement of "this is social studies, everyone!" Rather, Jules stealthily integrated this social studies experience by masking social studies content within the transition time.

This creative example of social studies was one of many we observed over the course of one school year in Jules' classroom. The purpose of this study is to explore the ways in which two teachers, Jules (a $1^{\text {st }}$ grade teacher) and Natasha (a $5^{\text {th }}$ grade teacher), integrated (intentionally or not) social studies content and skills throughout the day. In the United States, where social studies in the elementary grades is frequently marginalized (Fitchett \& Heafner, 2010), many teachers have been asked to or have taken it upon themselves to integrate social studies with other subject areas, especially with language arts (Boyle-Baise, Hsu, Johnson, Serriere, \& Stewart, 2011; Heafner, 2017). This study contributes to our understanding of what and how social studies can be taught in elementary classrooms with implications for future research and teacher practice within and beyond the United States.

\section{School Curriculum and Social Studies Integration}

There are two interrelated frameworks that inform this study: Eisner's (1985) description of the five aspects of school curriculum (formal, delivered, learned, hidden, and null) and Hinde's (2015) identification of healthy, fractured, and stealthy social studies integration. For this study, our focus was on Eisner's (1985) formal, hidden, and null curricula. As Eisner explains:

- formal curriculum is what all teachers intend to teach (e.g., content standards or textbooks),

- hidden curriculum is what students leave a lesson knowing or understanding — overtly or inadvertently, and 
- $\quad$ null curriculum is what students do not have an opportunity to learn (i.e., what is not explicitly taught), which sends implicit messages about the (lack of) importance of certain information and experiences.

Some argue that the absences of social studies in elementary schools is null curriculum, resulting in the devaluing of social studies instruction based on the minimal time spent on it or the absence of it altogether (Fitchett, Heafner, \& VanFossen, 2014). When a teacher integrates social studies into other content areas in ways that do not overtly appear in their lesson plans, such as Jules exposing her students to different languages during a transition time, one could interpret it as hidden curriculum.

Hinde describes three types of social studies integration in elementary classrooms: healthy, fractured, and stealthy $(2015$, p. 25). Healthy integration explicitly connects social studies to reading/language arts (most often) as well as students' lives, as tools to access social studies content and skills. For example, while learning about text features and studying currency, students use captions, headings, and tables in informational texts to identify currency from around the world. Fractured integration is when social studies is presented in disjointed or shallow ways and serves only to enhance reading/language arts instruction. For example, when introducing the historical fiction genre and studying the American Revolution, students simply read a passage from Johnny Tremain (Forbes, 1943). Instruction is limited to the language arts conventions about historical fiction and ignores authorship, sourcing, and other relevant aspects of historical inquiry. Stealthy integration is when teachers disguise social studies content as language arts lessons because of instructional mandates (e.g., required instructional minutes or test preparation). In stealthy integration, the social studies content may be rich, but the aim is to teach reading/language arts skills (Hinde, 2015, p. 25). For example, teachers may covertly integrate geographic descriptions of place in reading and writing tasks (Sekeres \& Gregg, 2008). The challenge associated with stealthy social studies is a lack of understanding of the distinct pedagogy associated with the social studies.

\section{Literature Review}

Social studies is a multi-disciplinary school subject that draws on content from a range of disciplines, including, but not limited to civics, economics, geography, and history. In our study, we operationalize social studies as the content and skills which "utilize diverse perspectives and skills to accomplish common goals" and "analyze cause and effect relationships" (NCSS, 2010, p. 163) which may occur within a specified social studies lesson or other subject areas and times during the academic day. Thus, we identified and examined examples of social studies in the formal, hidden, and null curricula. 


\section{Social Studies in U.S. Elementary Schools}

The marginalization of social studies in the U.S. elementary curriculum is welldocumented (e.g., Heafner \& Fitchett, 2010; Houser, 1995). Although marginalization of elementary social studies is not as well-documented in educational research in countries such as Canada, the integration of social studies into reading and language arts is nonetheless useful as teachers in any geographical context might have blended subject areas (e.g., through "humanities" courses instead of separate social studies and language arts classes) and might want to consider their use of unstructured time.

Preservice elementary teacher candidates in the United States have reported fewer social studies experiences (coursework and fieldwork) in comparison to other subject matter (Hawkman, Castro, Bennett, \& Barrow, 2015), which makes sense given the lack of attention to social studies in U.S. elementary classrooms. Presumably, if the subject is disappearing from classrooms, preservice teachers have fewer opportunities to see good social studies instruction or practice delivering it in a field practicum. Further, the lessons they reported seeing were often textbook-based (e.g., Zhao \& Hoge, 2005), focused on literacy skills (Boyle-Baise, Hsu, Johnson, Serriere, \& Stewart, 2011), or minimized social studies content (DiCamillo, 2010; Slekar, 1998). Despite these challenges, Fitchett, Heafner, and Lambert (2014) noted that elementary teachers who reported more autonomy (i.e., ability to make curricular decisions) reported more time teaching social studies. Huck (2018) documented the experiences of two such elementary teachers, Kim and Nate. These teachers shared their passion for social studies and, as a result, created opportunities for their students to engage in social studies experiences.

\section{Curriculum Integration}

Integrated approaches have shown potential for elementary social studies including increased instructional time and opportunities for students to authentically read and write, research suggests that curricular integration in elementary classrooms in the United States tends to prioritize language arts and minimize social studies learning (Alleman \& Brophy, 2010; Boyle-Baise et al., 2011; Sunal \& Sunal, 2008). Winstead-Fry (2009) found when teachers participated in professional development (PD) about interdisciplinary instruction, they preferred to design lesson in which subject matter was integrated. Also, teachers who participated in PD about interdisciplinary practices expressed beliefs that students were more engaged in content learning (Brugar, 2012).

Elementary teachers who integrate may do so to guarantee time for social studies instruction, so it is important to identify effective strategies that integrate social studies with language arts/reading (Strachan, 2015). More recently, Heafner (2018) found required ELA/social studies integration does not always occur due to confusion about when to integrate, time allotted for planning, and unclear administrative goals. In their work with pre-service 
teachers, Shifflet and Hunt (2019) argued for high-quality modeling of integration which unpack the complexities of integration and the need for intentional planning.

\section{Integrated Experiences in Social Studies with Other Subjects}

Research shows examples of healthy integration beyond social studies and language arts. We noted several studies documenting integration of science and literacy (Cervetti, Barber, Dorph, Pearson, \& Goldschmidt, 2012; Guthrie, McRae, \& Klauda, 2007; Vitale \& Romance, 2011), math and literacy, and social studies and literacy (e.g., Brugar, 2012; Halvorsen, Duke, Brugar, Block, \& Strachan, 2012). When teachers plan literacy to compliment social studies instruction, students' experiences are enhanced (Boyle-Baise et al., 2011). With mandates for increased instructional time on tested subjects, we hypothesized that elementary teachers stealthily integrate to include social studies in their classrooms in similar way to how Holloway and Chiodo (2009) found teachers "finding ways to teach Social Studies concepts" (p. 252).

In this paper, we focus on stealthy, healthy, and potentially fractured integration of social studies in two elementary classrooms. We found that integration was not limited to reading/language arts - there was evidence of integration with other subjects and during nonacademic times (e.g., snack time or morning meetings). This study expands our notions of social studies integration by identifying and describing both explicit and implicit ways in which two elementary teachers incorporate social studies content and skills (e.g., analyzing text, map reading) (Brugar \& Whitlock, 2018 throughout the academic day.

\section{Method}

\section{Research Design}

In light of the challenges (e.g., time, curricular priority) associated with teaching elementary social studies, we sought to examine: How do two elementary teachers incorporate social studies content and skills throughout the academic day? We describe the ways two elementary teachers integrated social studies in healthy, stealthy, and fractured ways by employing case study (Yin, 2003). Case study was utilized because it allows for the examination of "specific phenomenon such as a program, an event, a person, [or] a process" (Merriam, 1988, p. 9). We do not seek to compare cases but rather, we are examining social studies integration as a phenomenon in elementary classrooms from different contexts (grade level, location, etc.).

\section{Settings and Participants}

The classrooms were located in two regions of the United States (Midwest and South) but, similar socioeconomic communities — suburban with household incomes and parental education levels well above each state's average. Neither school's demographics are consistent 
with the state average for race, ethnicity, and socioeconomic status (SES) (See Table 1). We selected these schools' settings because elementary school teachers in high-SES communities tend to have more formalized time for social studies than their counterparts in low-SES communities (Berson \& Camicia, 2013; Burstein, Hutton, \& Curtis, 2006; Camburn \& Han, 2011; Pace, 2008). This situation would allow for the possibility to see social studies being taught in these classrooms and we entered into classroom with greater confidence that social studies instruction was, at least, expected to be integrated into other subjects if not a "standalone" subject on its own.

Jules and Natasha were our two elementary school teacher participants. Both teachers were recommended by district administration based on their teaching experiences and comfort having researchers in their classrooms. Each teacher followed state-approved standards for reading/language arts, math, science, and social studies. Further, students are not tested on social studies content or skills in grades one or five, in either state.

Jules was entering her 27 th year of teaching. She taught in a variety of grades in early elementary classrooms, and served as a reading specialist and an enrichment teacher in two different states. She had been teaching first grade at her current school for four years. Jules described her approach to social studies and interdisciplinary experiences in her classroom as "crossover times" - spaces in which she was able purposely select social studies materials (e.g., guided reading selections, informational writing prompts) with her students. She noted teaching social studies every other day during the school year.

Natasha had taught for 19 years in three states including the last decade at her current school. Natasha's approach to social studies was one of transmission. She used the textbook to guide the social studies information presented, acknowledging the need to supplement materials for various units of study. For example, during their unit on Colonial America, Natasha designed a project in which the students used various non-fiction trade books to develop first-person narratives about colonial life. When asked about interdisciplinary instruction, she expressed an interest in integrating language arts skills and social studies or science content. Additionally, Natasha mentioned that she read various historical fiction books to her students. Similar to Jules, Natasha taught social studies every other day for approximately 45 minutes.

\section{Data Collection Procedures}

Over the course of one academic year, we $(n=2)$ observed in one of the two identified elementary classrooms. Each researcher observed the first day of school in the classroom and one other day during the first week. During the year, we each completed 13 full-day observations and took detailed notes documenting subject area time, student-teacher actions, and the physical environment (Bogdan \& Biklen, 2006). Observations were planned (anywhere from three weeks to one day in advance) and took place approximately every three weeks. We decided to both plan 
and be consistent with our observations for several reasons. We were able to get to know the teachers and the school community to better understand the classroom culture. In turn, we believe there was room for more honest conversation and authentic instruction in our presence. In the course of the study, we observed only one instance in which plans were adjusted because of our presence. Natasha switched a research library session in order to share a class project on American colonial jobs.

During each observation day, we conducted a semi-structured interview to member check (Lincoln \& Guba, 1985), to contextualize field notes, and to allow each teacher to explain her intentions behind the instances of social studies. As we were studying integration more broadly, we also asked the teachers about their intentions behind integrating any subject area we observed. These interviews included questions about whether or not the integration was specifically planned or unplanned, and how closely the integration connected to the curricula.

\section{Data Analysis}

Prior to our first classroom observations, we began with deductive codes (Merriam \& Tisdell, 2016) using the Appendix 1: Essential Social Studies Skills and Strategies (NCSS, 2010) as identifiers for social studies experiences throughout the academic day. There are 119 skills and strategies identified in this document which are sub-divided into five categories: literacy skills, critical thinking skills, research-based literacy strategies for teachers, learning strategies, and personal interactional and civic engagement strategies. We selected to use this document because it is an established list from the largest organization devoted to K-16 social studies and it focuses on skills that transcend grade levels to allow for comparisons across contexts (and for a more robust analysis and discussion of social studies skills, please see Brugar and Whitlock, 2018). During our observations, we identified instances of social studies content being present. In addition to identifying the social studies skills, we included inductive codes for each instance of social studies with three additional markers: time of day, grouping (whole or small), and initiation (teacher or student).

Following our first week of school observations $(n=7)$ and using our initial codebook, together we coded the first five observations to establish common definitions and understandings. We amended our codebook to reflect these conversations. As the academic year unfolded, we coded the field notes from each observation within two weeks of it occurring. For these field notes, first we independently read and identified instances of social studies occurring the school day. We also identified "missed opportunities"- these were instances in which we identified an opportunity or possibility to extend social studies content or skills with the students (null curriculum). After coding individually, we discussed our individual coding. In instances of disagreement, we reviewed the field notes, discussed our individual understandings of the coded items, and worked toward a common understanding. In working toward a common 
understanding, each researcher was open to the other's insights in order to resolve all inconsistencies.

\section{Findings}

We found the integration of social studies occurred most often during non-academic time, followed by language arts/reading time, then math and science instruction (Table 2). Most often, social studies integration was initiated by teachers and presented as part of whole group instruction (Table 3), which indicates that most integration was intentional, as opposed to unintentional integration that was more often initiated by students or discussed with a small group. The majority of these instances of social studies integration involved disciplines of geography followed by history (see Table 4). Beyond noting the number of instances observed in these classrooms, we have presented our findings in greater detail in terms of healthy, stealthy, and fractured integration (see Table 5).

\section{Healthy Integration}

There were many examples of healthy integration during the language arts/reading instruction blocks (approximately 90 minutes in each classroom). Typically, this is where social studies integration occurs in an elementary classroom. (Hinde, 2015; Lintner, 2011). As part of their reading instruction, fifth graders are introduced to the genre of historical fiction. This genre study, as well as others, is supported by a textbook in which example readings are provided. From this textbook, Natasha's students read about a Navajo boy and his grandfather, a World War II Navajo Code Talker. Natasha introduced this story by defining historical fiction and brought in historical information (e.g., WWII occurred in the twentieth century), geographic reminders (e.g., Arizona is west of Oklahoma), and cultural commentary (e.g., Navajo language is beautiful). This example of healthy integration of social studies was teacher-initiated with attention to students' common (mis)conceptions of historical fiction and WWII Code Talkers.

Throughout the year, Natasha integrated historical fiction, particularly during the postlunch read aloud time. Notably, Natasha read Ghost Hawk (Cooper, 2013) and Out of the Dust (Hesse, 1998) to her students and identified both as "above reading level" for her fifth-graders. The read aloud provided an opportunity to expose her students to various relevant historical events through fiction which is often more engaging for readers. In addition, she hoped to connect their own experiences and their understandings of United States history-both within and beyond the historical time periods she taught. Natasha read a passage called "Hope" about snow from Out of the Dust (Hesse, 1998, p. 176.) After which, Natasha stopped to ask her students, "Do we know what time of year this is happening?" A student responded quickly, "It's winter because they are talking about snow." Natasha nodded with approval to the student's careful listening to the story along with the geographic connection she made. Her students were 
able to develop and practice social studies skills (e.g., reflection, summarizing, asking questions) (NCSS, 2010) during this unstructured time, even though no "formal" lessons were taught.

With similar understandings of content and her first graders, Jules planned to read The Relatives Came (Rylant, 1993) during a language arts lessons about making inferences in the text. One of the examples of an inference in the book was social studies-related, where the author writes that her relatives "came up from Virginia." Recognizing this opportunity, Jules displayed a U.S. map identifying Virginia. She asked her students to make an inference about where the narrator lives if her relatives "came up" from Virginia. Her students integrated their knowledge of cardinal directions in order to better understand the text. Jules had her students make inferences by using the United States map as a tool to help them understand the text.

We expand Hinde's (2015) definition of healthy integration beyond reading/language arts. One of the clearest examples of healthy integration we observed was in Natasha's math lesson on coordinates. In mathematics, fifth graders were exploring graphs and graphing. Natasha used her students' understandings of the math skill of coordinates and applying this skill to map reading. Interpreting information from graphic representations such as maps is also a language arts skill (CCSS, 2010; NCSS, 2010). This lesson exemplifies Natasha's use of specific pedagogical practices in math, social studies and language arts in order for students to practice skills from three different subject areas and applying this knowledge to an authentic activity.

\section{Stealthy Integration}

Hinde (2015) described stealth integration as only occurring between social studies and language arts — where social studies content may be present, but it appears masked as a language arts lesson. In the case of these two classrooms, we did not limit examples of social studies integration to only language arts lessons. In fact, we found social studies content being "taught" during non-academic times such as snack time or morning meeting (Whitlock \& Brugar, 2019).

A regular practice in Jules' classroom was for students to silently read after coming in from lunch. The students choose books from "book boxes" placed around the room that Jules filled with books and magazines with social studies topics. Students were free to select from several nonfiction books about various countries and cultures, biographies of notable historical figures, National Geographic World magazines, and age appropriate fiction. As students read, Jules noted which books and topics were the most popular with students and populated her classroom with more books on similar topics. These purposeful choices and observation allowed Jules to use these books to model explicit skills in her language arts lessons. She asked students to look through the "best of the best" informational books and find the different text features (e.g., bold print, captions, glossary, index, table of contents) and modeled her expectations with a book called South Korea (Rudolph, 2015). In this case, the language arts skills were emphasized over the social studies content. 
Jules was especially skilled at engaging students in content during informal classroom time. During snack times throughout the year, her students explored the world map, engaged in discussions about civil disobedience as it related to Martin Luther King Jr. Day, watched YouTube clips about other cultures, and sang songs and learned words in other languages. Students initiated many of these examples (such as asking about the world map, or about why Martin Luther King Jr. Day is celebrated). During one snack time early on in the school year, a group of students noticed the large, colorful map of the world that hung in Jules' room. As they were eating snack, and began peppering Jules with social studies questions: "Where is New Mexico?" "What is this chunk [referring to the continent of South America]?" "Where is Korea? Why is it blue?" Jules answered some questions, explaining that the "chunk" is a continent named South America, and that "cartographers make the countries different colors because they are easier to see. Korea is not a blue country." When a student asked a question she did not know the answer to, she took time to investigate, modeling for the students how to search Google for information on "how Europe got its name." In this example, Jules used the unstructured time of snack to engage in students' questions and interests that were related to geography.

In this case, these investigations may not have happened if the students had not been interested in the map of the world they had just discovered hanging in the room. Jules answered the students' questions very informally. Although this was not a planned interaction, Jules did recognize that many of her students continued to be interested in maps. She added more books about countries around the world into her classroom library for students to read during silent reading time and added games and puzzles with maps to her room for students to play with during indoor recess and free choice time - all unstructured spaces (Whitlock \& Brugar, 2019). Jules had a keen knowledge of first graders and content thus, she was able to embrace spontaneity and chose to further these discussions.

Classroom economies are a frequent practice in elementary classrooms to reinforce responsible behavior (e.g., Broome \& Preston-Grimes, 2011; Kourilsky, 1977). With this in mind, Natasha opened the "snack store" during snack time in fifth grade, where students could purchase food with punches on a card that they earned throughout the day. Students earned punches for completing required classroom assignments in timely ways as well as additional tasks like their classroom job. In Natasha's class, she appeared to be using snack time as a space for students to interact with this classroom economy and make purchases if they chose to do so. This application of economics has clear connections to social studies although it was not explicitly connected to the fifth grade social studies curriculum in Oklahoma. This example is spontaneous, as there is no guarantee that students will participate in the economy by purchasing anything from the "snack store" during this time.

In both classrooms, we observed examples of integration of social studies in math. In first grade, Jules explained how to play the "Penny-Dice" game. This game is a suggested instructional practice in the Jules' math curriculum that she is required to follow, which allows 
students the opportunity to practice counting in one-to-one correspondence. As part of the game, students roll dice and pick up the amount of pennies shown on the dice. Once each group completed the game, Jules asked if they can "exchange" the pennies to make nickels or dimes. ("Do we have five pennies we could exchange for one nickel?") In this case, Jules had structured an experience for students to stealthily integrate economics concepts of currency and exchange within the math lesson.

Another example of stealth integration was a student-initiated question as Jules read When I Was Five (Howard, 1999) as part of another language arts lesson. In this book, the narrator shares what he was dreaming about when he was five, like being a baseball star or a deep-sea diver. Jules read, "When I was five, I wanted to be a cowboy." Upon hearing this one student spoke up and said, “A cowboy isn't a job! How do you make money?” Recognizing her students' understanding of "job," Jules explained ways in which a cowboy is an occupation (e.g., they sell things, like milk or cattle to make money). Unconvinced, the first grader persisted, "I still don't get how being a cowboy is a job. A cowboy doesn't have a boss." Jules continued, "Not everybody's job has a boss. A cowboy is his own boss." This conversation about cowboys and jobs highlights Jules' ability to utilize pedagogically specific and appropriate questions and the understanding of content, to further student understanding.

\section{Fractured Integration}

Integration of social studies and language arts is the most common in elementary classrooms because the skills most closely overlap between these two subjects (Brugar \& Whitlock, 2018; Hinde, 2015). We found many examples of healthy and stealthy integration with language arts; however, we also found that the most fractured integration (i.e., disjointed or shallow) came during language arts time.

Frequently, Natasha used historical fiction to introduce social studies topics; however, the historical content of these reading choices were rarely discussed beyond a read aloud session. During one reading of Out of the Dust, Natasha read, "Mrs. Love is taking application for boys to do CCC work. Any boy between eighteen and twenty-eight can join" (Hesse, 1998, p. 181). Following this sentence, a student asked, "What is the CCC?" CCC stands for the Civilian Conservation Corps and was a U.S. public work program from 1933 to 1942. Many of the sidewalks in Natasha's school community were created by the CCC and have stamps indicating this connection.

The fifth-grade curriculum in Oklahoma focuses on U. S. history from 1600-1800, but very few of these read-aloud selections took place during these times. A Long Way From Chicago (Peck, 2000) is historical fiction that takes place during 1929-1942, and Fuzzy Mud (Sachar, 2015) is a science-fiction story with historical elements that plays with timelines in the past, present, and future. Natasha had no mandates to read or not read during this time nor did 
she have directives on what to read to her students during this time, and the fact that she chose historical fiction mostly speaks to her love of the genre. But Natasha's fifth grade students were exposed to texts from various time periods in United States history while studying a completely different time period in their scheduled social studies time, which could make the integration fractured.

\section{Missed Opportunities}

As part of our analysis we identified "missed opportunities" to further an exploration of social studies content or skills with the students. It is possible that Natasha and Jules could have extended many of the examples we previously shared but in this section we note where there was little, if any, connection made to social studies. For example, as part of her morning announcements, Jules talked about the devastating flood in India and shared that the school was collecting donations. This simple announcement presented multiple social studies opportunities from environmental concerns to notions of interdependence.

Natasha asked students to watch a video called Dear America: So Far Away From Home, Mary Driscoll (Dear America). The story is set in the 1840s when a young Irish girl immigrated to Lowell, Massachusetts to work in the textile mills. Natasha did very little to historically or geographically contextualize the story for her students. However, there was an opportunity to discuss change over time in terms of the setting to this story. Both Dear America and Ghost Hawk (Cooper, 2013) are set in Massachusetts but Ghost Hawk describes a more rural setting whereas Dear America describes a more urban environment due to industrialization.

\section{Discussion}

These findings suggest that social studies can, in fact, appear in many ways during the school day. However, we are cautious of the examples of integration we observed. It is our understanding that healthy integration is more desirable than stealthy integration when students may not recognize it or fractured integration when the integration is unclear. In some cases, the social studies was immediately apparent to students while, in some instances, the connections to social studies concepts and content was less obvious. Over the course of 26 observations in two different schools, we observed social studies integrated into nearly every subject area as well as during non-academic times such as morning transitions or snack time (See Table 2) (Whitlock \& Brugar, 2019). Although it would appear to be good news that social studies is observed so often, the quality of social studies matters more than the quantity (Table 5). With the examples we have shared, how might we further strengthen the social studies presented in these and other elementary classrooms?

Because social studies and language arts are so often paired as integrated subjects in elementary classrooms in the United States, it was concerning to see that the integration of these 
two subjects was the most fractured. This suggests that perhaps teachers still need professional development and guidance around how to integrate social studies and language arts in healthy ways into the formal curriculum, especially if this is a suggestion most often given to teachers as a way to keep the social studies from disappearing in their classrooms. We do know that healthy integration is possible, but teachers need richer, detailed examples of what healthy integration could look like at a wide variety of grade levels and with different subject areas.

Hinde's (2015) definition of "stealth" social studies indicates social studies is most often stealthily integrated into language arts instruction. However, we did not find this to be the case (Tables 2 and 3). The evidence of social studies instruction occurring during non-academic times indicates that perhaps the teachers were stealthily integrating social studies during times of the day when no instruction was required to take place. Identifying instances of stealthy social studies integration during unstructured spaces might encourage teachers to critically reflect on their instructional practices and the possibilities to incorporate content and skills in creative ways across school subjects. As a result, students have the opportunity to more deeply explore concepts and to try and make sense of the complexity associated with many social studies concepts, as well as the interconnectedness of school subjects to life beyond school.

It appears on the surface that these teachers are stealthily integrating social studies throughout the school day. However, we believe teachers and teacher educators must be cautious of their integration practices. In these examples, we as researchers were able to identify that social studies was being integrated, but it was not always evident that the teachers were aware of the integration and even more rarely did we observe the teachers being explicit with their students about their integration. In other words, at times the hidden curriculum was also hidden to the teachers. Even though they were intentionally choosing to integrate social studies outside of the formal curriculum, they did not always appear to do this in healthy ways. Natasha wanted her students to enjoy history so she integrated historical fiction texts. In an effort to recognize the individual histories and cultures of her students, Jules wove books, songs, and student expertise throughout the academic day. Neither teacher made these decisions explicit to their students, nor did they connect these ideas to social studies lessons. Also, many of these interactions were unplanned and spontaneously initiated by the students, which raises questions about how feasible it may be for teachers to come up with healthy integration on the spot. And it raises the question of whether healthy integration is or should be spontaneous.

\section{Conclusion}

We are concerned that stealthy integration might result in a lack of recognition of social studies among students, therefore making the integration fractured. If the social studies content is unrecognizable, then perhaps it becomes shallow, and does not enhance nor deepen students' knowledge and understanding. Even when the integration was healthy, if the students are unaware of it, does it become fractured? If the most social studies content is being delivered 
during unstructured time, do students miss an opportunity to apply that content within their formal lessons?

In the end, we are encouraged, but not satisfied, by the amount of social studies we observed in both of these classrooms, but many more questions remain. More research needs to be done to examine the integration of social studies in other grade levels and in other socioeconomic settings. We need to develop rich examples of healthy integration in all subject areas and deliver these examples directly to classroom teachers and teacher candidates.

\section{Children's Book References}

Cooper, S. (2013). Ghost hawk. New York, NY: Margaret K. McElderry Books. Forbes, E. (1943). Johnny Tremain. New York, NY: Houghton Mifflin Company. Hesse, K. (1998). Out of the dust. New York, NY: Scholastic.

Howard, A. (1999). When I was five. Boston, MA: Houghton Mifflin Harcourt Books for Young Readers.

Peck, R. (2000). A long way from Chicago. New York, NY: Penguin Books.

Rudolph, J. (2015). South Korea. New York, NY: Bearport Publishing.

Rylant, C. (1993). The relatives came. New York, NY: Aladdin Books.

Sachar, L. (2015). Fuzzy mud. New York, NY: Delacorte Books for Young Readers.

\section{References}

Alleman, J., \& Brophy, J. (2010). Effective integration of social studies and literacy. In M. E. McGuire \& B. Cole (Eds.). Making a difference: Revitalizing elementary social studies (pp. 51-66). Silver Spring, MD: National Council for Social Studies.

Berson, I. R. \& Camicia, S. (2013). Early childhood social studies: A national study of challenges and promising practices. In J. Passe \& P. G. Fitchett (Eds.), Charlotte, NC: Informational Age Publishing.

Bogdan, R. \& Biklen, S. K. (2006). Qualitative research in education: An introduction to theories and methods. Upper Saddle River, NJ: Pearson.

Boyle-Baise, M., Hsu, M. C., Johnson, S., Serriere, S. C., \& Stewart, D. (2011). Trying to revalue elementary social studies: dilemmas and insights. Social Studies Research and Practice, 6(2), 135-150.

Broome, J. P., \& Preston-Grimes, P. (2011). Open for business: Learning economics through social interaction in a student-operated store. The Journal of Social Studies Research, $35(1), 35-59$.

Brugar, K. A. (2012). What difference does curricular integration make? An inquiry of fifth graders' learning of history through the. Use of literacy and visual arts skills. Doctoral Dissertation, Michigan State University, East Lansing, MI. 
Brugar, K. A. \& Whitlock, A. M. (2018). Social studies skills or something else? An analysis of how the Essential Social Studies Skills and Strategies reflects social studies instruction. The Clearinghouse: A Journal of Educational Strategies, Issues, and Ideas, 91(3), 111117.

Burstein, J., Hutton, L., \& Curtis, R. (2006). Elementary social studies: To teach or not to teach. Journal of Social Studies Research, 30(1), 15-20.

Camburn, E. M., \& Han, S. W. (2011). Two decades of generalizable evidence on U.S. instruction from national surveys. Teachers College Record, 113(3), 561-610.

Cervetti, G. N., Barber, J., Dorph, R., Pearson, P. D., \& Goldschmidt, P. G. (2012). The impact of an integrated approach to science and literacy in elementary school classrooms. Journal of Research in Science Teaching, 49(5), 631-658.

DiCamillo, L. (2010). "Fun” pedagogy curtails intellectual rigor in a U.S. History class. The Journal of Social Studies Research, 34(2), 175-207.

Eisner, E. (1985). Five basic orientations to the curriculum. In E. Eisner, The educational imagination: On the design and evaluation of school programs (pp. 61-86). New York, NY: Macmillian.

Fitchett, P. G., \& Heafner, T. L. (2010). A national perspective on the effects of high-stakes testing and standardization on elementary social studies marginalization. Theory and Research in Social Education, 38(1), 114-130.

Fitchett, P. G., Heafner, T. L., \& Lambert, R. G. (2014). Examining elementary social studies marginalization: A multilevel model. Education Policy, 28(1), 40-68.

Fitchett, P. G., Heafner, T. L. \& VanFossen, P. (2014). An analysis of time prioritization for social studies in elementary classrooms. Journal of Curriculum and Instruction, 8(2), 735.

Guthrie, J. T., McRae, A., \& Klauda, S. L. (2007). Contributions of Concept-Oriented Reading Instruction to knowledge about interventions for motivations in reading. Educational Psychologist, 42, 237-250.

Halvorsen, A., Duke, N.K., Brugar, K., Block, M., \& Strachan, S. (2012). Narrowing the Achievement Gap in Second-Grade Social Studies and Content Area Literacy: The Promise of a Project-Based Approach. Theory and Research in Social Education, 40 (3), 198-229.

Hawkman, A. M., Castro, A. J., Bennett, L. B., \& Barrow, L. H. (2015). Where is the content? Elementary social studies in preservice field experiences. The Journal of Social Studies Research, 39, 197-206.

Heafner, T. L. (2018). Elementary ela/social studies integration: Challenges and limitations. The Social Studies 109(1), 1-12.

Heafner, T. L. (2017). More social studies? Examining instructional policies of time and testing in elementary school. Journal of Social Studies Research. Retrieved from https://doi.org/10.1016/j.jssr.2017.08.004 
Hinde, E. (2015). The theoretical foundations of curriculum integration and its application to social studies instruction. In Bennett, L. \& Hinde, E.R. (Eds.), Becoming integrated thinkers: Case studies in elementary social studies (pp. 21-29). Silver Spring, MD: National Council for the Social Studies.

Holloway, J. E., \& Chiodo, J. J. (2009). Social studies is being taught in the elementary school: A contrarian view. Journal of Social Studies, 33(2), 235-261.

Houser, N. (1995). Social studies on the back burner: Views from the field. Theory and Research in Social Education, 23(2), 147-168.

Huck, A. (2019). Elementary social studies content integration in CCLS: An analysis of content integration, The Social Studies, 110(1), 1-16, DOI: 10.1080/00377996.2018.1524359

Kourilsky, M. (1977). The Kinder-Economy: A case study of Kindergarten pupils' acquisition of economic concepts. The Elementary School Journal, 77(3), 182-191.

Lincoln, Y. S. \& Guba, E. G. (1985). Naturalistic Inquiry. Newbury Park, CA: Sage Publications.

Lintner, T. (2011). Integrative strategies for the k-12 social studies classroom. Charlotte, NC: Information Age Publishing.

Merriam, S. B. (1988). Case study research in education: A qualitative approach. San Francisco, CA: Jossey-Bass.

Merriam, S. B. \& Tisdell, E. J. (2016). Qualitative research: A guide to design and implementation. San Francisco, CA: Jossey-Bass.

National Council for the Social Studies. (2010). National curriculum standards for social studies: A framework for teaching, learning, and assessment. Washington, D.C.: Author.

National Governors Association Center for Best Practices, \& Council of Chief State School Officers (2010). Common Core State Standards. Retrieved from http://www.corestandards.org/ELA-Literacy/

Office of Educational Quality and Accountability (2014). Oklahoma school profiles. Retrieved from: http://www.schoolreportcard.org/report-card/district/14I029/year/2013

Pace, J. L. (2008). Inequalities in history-social science teaching under high stakes accountability: Interviews with fifth-grade teachers in California. Social Studies Research and Practice, 3(1), 32-60.

Sekeres, D. C. \& Gregg, M. (2008). The stealth approach: Geography and poetry. Journal of Geography 107(1), 3-11.

Shifflet R. \& Hunt C. S. (2019) “All teaching should be integration”: Social studies and literacy integration in preservice teacher education. The Social Studies, 110(6), 237-250. DOI: 10.1080/00377996.2019.1635978.

Slekar, T. D. (1998). Epistemological entanglements: Pre-service elementary school teachers' "apprenticeship of observation" and the teaching of history. Theory and Research in Social Education, 26(4), 485-508.

Strachan, S. L. (2015). Kindergarten students' social studies and content literacy learning from interactive read-alouds. The Journal of Social Studies Research, 39, 207-223. 
Sunal, C. \& Sunal, D. (2008). Reports from the field: Elementary teacher candidates describe the teaching of social studies. The International Journal of Social Education, 22(2), 2948.

U.S. Department of Education, National Center for Education Statistics (2012). Digest of Education Statistics, 2013 (NCES 2012-2013).

Vitale, M. R., \& Romance, N. R. (2011). Adaptation of a knowledge-based instructional intervention to accelerate student learning in science and early literacy in grades 1 and 2 . Journal of Curriculum and Instruction 5(2), 79-93.

Whitlock, A .M. \& Brugar, K. A. (2019). Teaching elementary social studies during snack time and other unstructured spaces. Journal of Social Studies Research, 43(3), 229-239.

Winstead-Fry, S. (2009). On borrowed time: How four elementary preservice teachers learned to teach social studies in the NCLB era. Social Studies Research and Practice, 4(1), 31-41.

Yin, R. K. (2003). Case study research: Design and methods (3rd ed.). Thousand Oaks, CA: Sage.

Zhao, Y., \& Hoge, J. D. (2005). What elementary students and teachers say about social studies. The social studies, 96(5), 216-221. 
Brugar \& Whitlock, 2020

Canadian Social Studies, Volume 51, Issue No. 1

Table 1

School Demographics

\begin{tabular}{|c|c|c|c|c|}
\hline & $M I$ & Jules' School & $O K$ & Natasha's School \\
\hline $\begin{array}{l}\text { Asian or } \\
\text { Asian/Pacific } \\
\text { Islander }\end{array}$ & $3 \%$ & $46 \%$ & $2 \%$ & $5 \%$ \\
\hline White & $68 \%$ & $45 \%$ & $59 \%$ & $75 \%$ \\
\hline $\begin{array}{l}\text { African- } \\
\text { American }\end{array}$ & $18 \%$ & $4 \%$ & $9 \%$ & $3 \%$ \\
\hline Hispanic & $7 \%$ & $3 \%$ & $15 \%$ & $12 \%$ \\
\hline Multiracial & $3 \%$ & $2 \%$ & & \\
\hline $\begin{array}{l}\text { American } \\
\text { Indian/Alaska } \\
\text { Native }\end{array}$ & $1 \%$ & $0 \%$ & $15 \%$ & $5 \%$ \\
\hline $\begin{array}{l}\text { Hawaiian } \\
\text { Native/Pacific } \\
\text { Islander }\end{array}$ & $0 \%$ & $0 \%$ & & \\
\hline FARL & & $2 \%$ & $62 \%$ & $32 \%$ \\
\hline
\end{tabular}

NCES, 2013-2014

State of Oklahoma Office of Educational Quality and Accountability, 2013-2014 
Brugar \& Whitlock, 2020

Table 2

Number of Observed Instances of Social Studies Integration

Subject/Time Frame

Number of Instances of Social Studies

Announcements

Language Arts/Reading

Snack Time/Non-Academic

Math

Science

Social Studies

Table 3

Instances of Social Studies Integration

\begin{tabular}{lr}
\hline & Number of Instances \\
\hline Teacher Initiated & 122 \\
Student Initiation & 20 \\
Whole Group Instruction & 129 \\
Small Group Instruction & 4 \\
\hline
\end{tabular}

\section{Table 4}

Social Studies Content Areas Integrated

Number of Instances

Civics

Economics

Geography

History

Social Studies, generic 


\section{Table 5}

Examples of Integration

\begin{tabular}{|c|c|c|}
\hline Type of Integration & Definition & Observed Examples \\
\hline Healthy & $\begin{array}{l}\text { social studies connects explicitly to } \\
\text { reading/language arts (most often) as well } \\
\text { as students' lives, as tools to access social } \\
\text { studies content. }\end{array}$ & $\begin{array}{l}\text { Fifth grade math lesson on the } \\
\text { use of coordinates which was } \\
\text { applied to map reading }\end{array}$ \\
\hline Stealthy & $\begin{array}{l}\text { social studies is presented in disjointed or } \\
\text { shallow ways and serves only to enhance } \\
\text { reading/language arts instruction }\end{array}$ & $\begin{array}{l}\text { First grade snack time, group of } \\
\text { students noticed a large, colorful } \\
\text { map of the world asked Jules } \\
\text { various social studies questions: } \\
\text { "Where is New Mexico?" } \\
\text { "What is this chunk [referring to } \\
\text { the continent of South } \\
\text { America]?" "Where is Korea? } \\
\text { Why is it blue?" Jules answered } \\
\text { some questions, explaining that } \\
\text { the "chunk" is a continent } \\
\text { named South America, and that } \\
\text { "cartographers make the } \\
\text { countries different colors } \\
\text { because they are easier to see. } \\
\text { Korea is not a blue country." } \\
\text { When a student asked a question } \\
\text { she did not know the answer to, } \\
\text { she took time to investigate, } \\
\text { modeling for the students how } \\
\text { to search Google for information } \\
\text { on "how Europe got its name." }\end{array}$ \\
\hline Fractured & $\begin{array}{l}\text { social studies content is disguised as } \\
\text { language arts lessons }\end{array}$ & $\begin{array}{l}\text { Fifth-grade curriculum on U. S. } \\
\text { history from 1600-1800, A Long } \\
\text { Way From Chicago (Peck, } \\
\text { 2000) is historical fiction that } \\
\text { takes place during 1929-1942, } \\
\text { used as a read aloud }\end{array}$ \\
\hline
\end{tabular}

